\title{
POLITYCZNA AKTYWNOŚĆ POLAKÓW NA LITWIE
}

\author{
Adam Bobryk, Społeczne znaczenia funkcjonowania polskich ugrupowań politycznych
} w Republice Litewskiej 1989-2013, Siedlce 2013

\section{POLITICAL ACTIVITY OF POLES IN LITHUANIA}

\begin{abstract}
A review of the latest book by Adam Bobryk has the aim to present the most valuable points of the publication. The reviewer focuses his attention on the most important aspects described in the seven chapters of the book. He also observes that this is the first monograph describing political activities of the Polish community in the Republic of Lithuania. According to the author of the review the book by Adam Bobryk, despite a few insignificant errors, is an important position to read, and for any researcher of Polish-Lithuanian relations it is even mandatory.
\end{abstract}

Key words: Poland; Lithuania; political activity of the Polish community in the Republic of Lithuania; Polish-Lithuanian relations

Streszczenie

Tekst jest recenzją najnowszej książki Adama Bobryka, w której autor stara się pokrótce przedstawić najważniejsze informacje zawarte w omawianej publikacji. Przytaczoczone zostałytu główne wątki opisane w siedmiu rozdziałach książki A. Bobryka. Recenzent zauważa też, że jest to pierwsza monografia opisująca działalność polityczną społeczności polskiej w Republice Litewskiej. Zdaniem autora recenzji książka Adama Bobryka, mimo kilku nieistotnych błędów, jest pozycją ważną, a dla badacza relacji polsko-litewskich wręcz obowiązkową.

Stowa kluczowe: Litwa; Polska; organizacje polskie w Republice Litewskiej; stosunki polsko-litewskie
MARCIN WAKAR,

Ośrodek Badań Naukowych im. Wojciecha Kętrzyńskiego w Olsztynie. Correspondence: marcin.wakar@gmail.com

This is an Open Access article distributed under the terms of the Creative Commons Attribution 3.0 PL License (creativecommons.org/licenses/by/3.0/pl/), which permits redistribution, commercial and non-commercial, provided that the article is properly cited. (C) The Author(s) 2015.

Publisher: Institute of Slavic Studies PAS [Wydawca: Instytut Slawistyki PAN] 

naukowym problematyka diaspory polskiej na Litwie poruszana jest wciąż dość rzadko. Powstało, co prawda, kilka profesjonalnych opracowań książkowych ${ }^{1}$, ale nikt dotąd nie zajął się rzeczowo ${ }^{2}$ współczesną polską reprezentacją polityczną w tym kraju. Dlatego też z nieukrywaną satysfakcją przyjąłem nową publikację dr. Adama Bobryka wydaną przez Siedleckie Towarzystwo Naukowe. Autor ten ma już bogaty dorobek naukowy dotyczący współczesnej problematyki Polaków z Litwy, w tym, przede wszystkim, ich narodowego odrodzenia na przełomie lat osiemdziesiątych i dziewięćdziesiątych XX wieku. Omawiana książka z pewnością wzbogaca nie tylko dorobek siedleckiego socjologa, ale też całej krajowej humanistyki.

Ponadpięćsetstronicowa publikacja składa się z siedmiu rozdziałów, bogatej bibliografii oraz indeksu osób w alfabecie łacińskim i cyrylicy. Rozdział pierwszy, zatytułowany "Polacy na Litwie w okresie walki o niepodległość Republiki", jest formą historycznego wprowadzenia w omawianą na dalszych stronicach problematykę. Autor opisuje status Polaków w Litewskiej Socjalistycznej Republice Radzieckiej, przemiany okresu tzw. pierestrojki i stosunek litewskiego ruchu niepodległościowego wobec społeczności polskiej. Przypomina też nieudane dążenia Polaków do utworzenia na Wileńszczyźnie Polskiego Kraju Narodowo-Terytorialnego ze stolicą w Nowej Wilejce oraz postawy Polaków wobec niepodległości Litwy.

Rozdział drugi, zatytułowany "Zwiększanie obecności Polaków w życiu publicznym poprzez działalność polskich ugrupowań o celach społeczno-politycznych", to omówienie aktywności dwóch organizacji, które zawiązały się w Wilnie: Związku Polaków na Litwie oraz, szerzej już dziś nieznanego, Kongresu Polaków Litwy. I właśnie opis tej drugiej organizacji wydaje się szczególnie ważny, gdyż dławi lansowaną współcześnie tezę o jedności politycznej litewskich Polaków. Jak stwierdza Adam Bobryk: „Utworzenie nowej organizacji zapewne było jednym z mechanizmów poszukiwania przez [Artura] Płoksztę możliwości działań w środowisku polskim i realizowania swej wizji, która nie była akceptowana w Związku [Polaków na Litwie]" (Bobryk, 2013, s. 110).

Trzeci rozdział („,Rola i znaczenie polskich partii oraz problem aktywności Polaków w innych ugrupowaniach politycznych") wprowadza czytelnika w zasadniczą część książki. Na jego stronach autor ukazuje niuanse polskiej aktywności politycznej na Litwie i obok znanej wszystkim (interesującym się choć trochę tamtejszymi Polakami) Akcji Wyborczej Polaków na Litwie opisuje inne nieistniejące dziś ugrupowania: Alians Mniejszości Narodowych Litwy - Alians Obywateli Litwy, Polską Partię Ludową, a także Polski Podkomitet w nie funkcjonującej już socjoliberalnej partii Nowy Związek oraz Klub Polaków na Litwie "ProLibera". A. Bobryk, co być może najistotniejsze, opisuje również działalność Polaków w litewskich ugrupowaniach politycznych. Właśnie ta ostatnie kwestia jest czytelnikowi z tzw. Korony zupełnie dotąd nieznana.

Kolejne dwa rozdziały („Między izolacją a współpracą. Polskie ugrupowania w samorządach Republiki Litewskiej” oraz „Uwarunkowania i proces kształtowania reprezentacji parlamentarnej polskich ugrupowań oraz jej aktywność na rzecz mniejszości polskiej")

\section{$\cdots \cdots$}

Wymienić tu trzeba m.in.: Bobryk (2005); Kurcz (2005); Srebrakowski (2000).

Istnieją, co prawda, dwie pozycje napisane wcześniej: Kawęcki (2013); Sidorkiewicz (2011), ale nie dają one pełnego obrazu funkcjonowania polskich ugrupowań politycznych na Litwie. 
to omówienie uczestnictwa polskich organizacji społecznych ${ }^{3}$ i politycznych w lokalnych władzach samorządowych i w litewskim parlamencie. W tej części książki autor chronologicznie opisuje wszystkie kadencje samorządów i parlamentów oraz najważniejsze problemy podejmowane przez polityków reprezentujących mniejszość Polską na Litwie, czyli kwestię pisowni nazwisk, dwujęzycznych tablic w rejonach zwartego zamieszkania Polaków, ograniczania polskojęzycznego szkolnictwa oraz zwrotu mienia zagarniętego przez władzę sowiecką. Istotnym wkładem autora w poszerzenie wiedzy na temat działalności politycznej Polaków z Litwy jest opracowanie tabel z wynikami wyborczymi organizacji i partii politycznych w poszczególnych regionach z uwzględnieniem: liczby uzyskanych głosów, odsetka uzyskanych głosów, liczby wystawionych list, miejsca partii w rankingu wyborczym, liczby partii biorących udział w podziale mandatów, liczby wystawionych kandydatów, liczby uzyskanych mandatów i ogólnej liczby mandatów w samorządzie. Ważne są także tabele dotyczące aktywności legislacyjnej posłów Polaków i aktywności podczas posiedzeń plenarnych Sejmu RL.

W rozdziale szóstym, "Polacy wobec wyborów prezydenckich i europarlamentarnych", Adam Bobryk opisuje przywrócenie urzędu prezydenta Republiki Litewskiej w 1992 r., a także pięć pierwszych prezydentur: Algirdasa Brazauskasa, Valdasa Adamkusa, Rolandasa Paksasa, ponownej Adamkusa i pierwszej kadencji Dalii Grybauskaité4. Już na początku przypomina nieufność litewskich Polaków wobec idei przywrócenia urzędu prezydenta, która spowodowana była napięciami w relacjach polska mniejszość - litewska większość. Jak zauważa:

Stwierdzano, że przywrócenie urzędu prezydenta należy poprzedzić przyjęciem nowej Konstytucji, która precyzyjnie określałaby kompetencje głowy państwa. Jednocześnie postulowano, by utworzyć Sąd Konstytucyjny, powołać rzecznika praw obywatelskich oraz inne organy, które miałyby w swoim zakresie działania ochronę praw człowieka i obywatela (Bobryk, 2013, s. 308).

Dużo miejsca poświęca też kandydaturze lidera AWPL, Waldemara Tomaszewskiego, na najwyższy urząd w państwie. W dalszej części rozdziału opisuje referendum akcesyjne i nadzieje, jakie polska mniejszość wiązała z wejściem Litwy w skład Unii Europejskiej. Ze szczegółami prezentuje też wybory do Parlamentu Europejskiego z 2009 r. i uzyskanie mandatu eurodeputowanego przez Waldemara Tomaszewskiego.

Ostatni rozdział, zatytułowany "Między deklaracjami a praktyką. Problemy polskiej mniejszości w świetle polityki państwa litewskiego i własnej aktywności społeczno-politycznej", to powrót do opisywanych już wcześniej wątków, które przeplatają się przez niemal całą książkę. Jest on więc formą (aczkolwiek, zdaniem autora tych słów, niekonieczną) podsumowania celów aktywności politycznej Polaków na Litwie i odnosi się do wspomnianych już problemów: pisowni nazwisk, dwujęzycznych tablic, oświaty i reprywatyzacji. Najistotniejszą kwestią poruszoną w tym rozdziale jest jednak rola mniejszości polskiej na Litwie w kontekście relacji międzypaństwowych Rzeczypospolitej Polskiej i Republiki Litewskiej.

Tekst książki zamyka zakończenie, w którym autor konstatuje:

Niewątpliwie jednak wszystkie inicjatywy [polityczne], pomimo wzajemnej konkurencji, a czasami nawet wrogości, były próbami poszukiwania mechanizmów zmiany pozycji Polaków w strukturze stratyfikacyjnej i pobudzenia aktywności. Działalność ich przyczyniła się do wzro-

3 Autor odnosi sie jedynie do Związku Polaków na Litwie, który wystawił własną liste w wyborach w 1990 i 1992 r. W związku ze zmianą ustawy o organizacjach społecznych, w kolejnych wyborach zamiast ZPL swą listę wystawiła powołana w tym celu Akcja Wyborcza Polaków na Litwie.

4 Druga kadencja Dalii Grybauskaitè nie mieści się w ramach czasowych, które obejmuje recenzowana książka. 
stu intensywności interakcji, ochrony tożsamości, wskazywania istotnych problemów społecznych, sposobów ich rozwiązywania, propagowania obowiązków wobec grupy, zainteresowania sprawami publicznymi. W efekcie również kształtowana była nowa elita polityczna (Bobryk, 2013, s. 435).

Książka Adama Bobryka to pozycja cenna, a dla zainteresowanego problematyką mniejszości polskiej na Wschodzie, wręcz obowiązkowa. Autor, opisując aktywność polityczną Polaków w Republice Litewskiej, ukazuje czytelnikowi całą litewską scenę polityczną, dzięki czemu można poznać wszystkie jej niuanse. Mocną stroną książki jest baza źródłowa. W bibliografii wymieniono prawie czterysta pozycji książkowych i artykułów napisanych po polsku, rosyjsku, angielsku i litewsku. Ponadto prezentuje ona obszerną bazę prasy polskiej, litewskiej oraz pochodzącej z innych krajów, w której poruszana jest problematyka funkcjonowania polskich ugrupowań politycznych na Litwie. Wymienia też akty prawne oraz witryny internetowe, maszynopisy i archiwalia, którymi posłużył się autor, pisząc książkę. Całość uzupełnia lista dziesięciu relacji czołowych działaczy polskich na Litwie zebranych przez autora.

Obowiązkiem recenzenta jest też wykazanie luk i nieścisłości w opisywanej publikacji. W przypadku książki Adama Bobryka to zadanie niełatwe. Najbardziej rzucającym się w oczy mankamentem jest brak opisu ewolucji światopoglądowej w Akcji Wyborczej Polaków na Litwie, która powstała jako partia centrolewicowa, a dziś można ją określić jako centroprawicową i konserwatywną. Poza tym trudno sformułować jakiekolwiek zarzuty pod adresem omawianej książki. Trafiają się czasami literówki lub błędy w nazwach własnych, jak np. na s. 395, gdzie autor pisze: Wileński Uniwersytet Edukologiczny, mając na myśli Litewski Uniwersytet Edukologiczny, ale nie wpływają one na treść książki, której lekturę należy uznać za godną polecenia.

\section{BIBLIOGRAFIA}

Bobryk, A. (2005). Odrodzenia narodowe Polaków w Republice Litewskiej 1987-1997. Toruń: Dom Wydawniczy "Duet”.

Bobryk, A. (2013). Społeczne znaczenie funkcjonowania polskich ugrupowań politycznych w Republice Litewskiej 1989-2013. Siedlce: Siedleckie Towarzystwo Naukowe.

Kawęcki, K. (2013). Polacy na Wileńszczyźnie 1990-2012. Warszawa: Europejskie Centrum Analiz Geopolitycznych.

Kurcz, Z. (2005). Mniejszość polska na Wileńszczyźnie. Wrocław: Wydawnictwo Uniwersytetu Wrocławskiego.

Sidorkiewicz, K. (2011). Między demokracją a buntem: Działalność polityczna i samorządowa Polaków w Republice Litewskiej (1988-2011). Elbląg: Wydawnictwo Państwowej Wyższej Szkoły Zawodowej.

Srebrakowski, A. (2000). Polacy w Litewskiej SRR 1944-1989. Toruń: Wydawnictwo Adam Marszałek. 